\title{
Does habitat loss affect the communities of plants and insects equally in plant-pollinator interactions? Preliminary findings
}

\author{
Hisatomo Taki $\cdot$ Peter G. Kevan
}

Received: 26 July 2006/ Accepted: 27 February 2007

(C) Springer Science+Business Media B.V. 2007

\begin{abstract}
Habitat loss is a major threat to biodiversity and ecosystem function. As habitats are lost, one factor affecting their community structures is the niche-width demand of species, which ranges from specialist to generalist. This study focused on specialist and generalist species in plant-pollinator interactions and tested the hypothesis that plant and pollinator communities become more generalized as habitat loss increases. The study was made in seven selected sites in southern Ontario, Canada, at the level of landscape that is characterized by distributed forests within intensively managed agricultural fields. We quantified both the degree of habitat loss and the degree of specialization/generalization for each of the plant and insect communities using a sampling method of hexagonal transects. Regression analysis indicated a significant relationship between the increase of habitat loss and the shift to generalization in insect, but not in plant, communities. Our results suggest that, in plant-pollinator interactions, insect communities are more sensitive and/or quicker than plant communities to respond to the effects of habitat loss.
\end{abstract}

Keywords Asymmetry · Forest loss · Generalist · Habitat degradation · Habitat fragmentation $\cdot$ Mutualism $\cdot$ Specialist

\section{Introduction}

Habitat loss is currently a major threat to biodiversity (e.g., Findlay and Houlahan 1997; Debinski and Holt 2000; Gurd et al. 2001; Steffan-Dewenter et al. 2002). Losses occurring within landscapes could result in habitat fragmentation (Fahrig 2003; Ewers and Didham 2006). Such landscape changes lead to perturbations in community structures and interspecific interactions within the communities (Steffan-Dewenter and Tscharntke 2002; Tscharntke and Brandl 2004). As habitats are lost, one factor affecting interspecific

H. Taki $(\bowtie) \cdot$ P. G. Kevan

Department of Environmental Biology, University of Guelph, Guelph, ON, CanadaN1G 2W1

e-mail: htaki@uoguelph.ca 
interactions is niche-width demand for both specialists and generalists (Wilson and Yoshimura 1994; Kassen 2002). Specialists have narrower niches than do generalists. Some specialists have been shown to be more vulnerable than generalists to habitat degradation (Kitahara and Fujii 1994; Kitahara et al. 2000).

Plant-pollinator networks are excellent examples of mutualistic interspecific interactions (Kevan and Baker 1983, 1999; Waser and Ollerton 2006). Pollen transfer by animals is essential for reproduction in most angiosperm species, and therefore pollinators provide a critical service in terrestrial ecosystems (Buchmann and Nabhan 1996; Allen-Wardell et al. 1998; Kearns et al. 1998; Kevan 2001). Such plant-pollinator interactions are also strongly dependant upon niche-width demands of both plant and pollinator species, both ranging from specialists to generalists (Rathcke and Jules 1993; Johnson and Steiner 2000; Olesen and Jordano 2002). Consequently, habitat loss certainly is expected to affect the relative composition of specialists and generalists comprising a community linked through plant-pollinator interactions (Fortuna and Bascompte 2006).

The debate on specialization and generalization in plant-pollinator interactions are still active (Waser and Ollerton 2006). It is widely accepted that the most stable pollination network evolve toward increasingly specialized interactions (Baker and Hurd 1968; Stebbins 1970). However, a certain mix of generalist and specialist mutualistic interactions co-exists in most ecosystems and it has been posited that stable pollination networks include evolution toward specialization and toward generalization (Kevan and Baker 1983, 1999). In general, pollinator/plant networks in ecosystems seem to include rather more generalized than specialized relationships (Proctor 1978; Herrera 1988; Waser et al. 1996; Johnson and Steiner 2000).

Our primary aim is to analyze the effects of habitat loss on communities of plants and their insect pollinators at the landscape level. In particular, we evaluate the changes in the relative representation of specialization and generalization in plant-pollinator interactions. Our specific hypothesis is that plant and pollinator communities become more generalized with increased loss of habitat.

\section{Materials and methods}

Study sites and hexagonal transect

Our study was done in Norfolk County of Ontario, Canada $\left(42^{\circ} 37^{\prime}-42^{\circ} 48^{\prime} \mathrm{N}, 80^{\circ} 25^{\prime}-\right.$ $\left.80^{\circ} 39^{\prime} \mathrm{W}\right)$. The region is located in southern Ontario's deciduous Carolinian forest zone, where the warm and dry southern climate is ideal for such an ecosystem that is not found elsewhere in Canada. Many plant species with high priority for conservation occur in the Carolinian forest zone (Allen et al. 1990; Waldron 2003). The landscape is flat, characterized by distributed fragments (patches) of forest within intensively managed agricultural fields of crops, such as corn, soybean, and tobacco.

In May and June of 2003, eight sites were selected with the aid of a Geographical Information System (GIS), ArcView (Version 3.3, ESRI, Redlands, CA, USA). At random, eight geographical points that fell within the forest polygons in the study region of Norfolk County were chosen. The criteria for accepting a randomly selected point included a minimum distance of $40 \mathrm{~m}$ from all edges of the forest polygons and a minimum separation distance of 4,500 $\mathrm{m}$ from any other chosen geographical points. All points selected in the laboratory were visited, using a Global Position System (GPS) (Garmin International, Olathe, KS, USA), and confirmed as to utility to be study sites. Selected points on or near a 
river, a pond or a path were rejected. The geospatial data of forest coverage was produced using aerial photography (1:30,000 and 1:50,000) obtained from the Ontario Base Map Series in 2003 (Ontario Ministry of Natural Resources, Peterborough, ON, Canada).

Each of the eight selected sites consisted of a hexagonal transect with $20 \mathrm{~m}$ sides with the chosen geographical point marking the center. In constructing the hexagonal transects, the direction of the first radial arm of each transect was randomly chosen by using a $1.5 \mathrm{~m}$ stick thrown in the air. The axes were marked with bamboo poles and a $120 \mathrm{~m}$ piece of rope demarcated the perimeter. Although a better choice for transect shape would be a circle, hexagonal transects were more practical.

One of the eight sites chosen in 2003 was rejected at the beginning of sampling in April 2004 because of flooding by a vernal pond.

\section{Insect and plant sampling}

To investigate the species richness and abundance of the flower-visiting insects as well as their plant interactions, a belt transect method (Banaszak 1980; Memmott 1999; Dicks et al. 2002) was applied to the hexagonal transects. The same seven hexagons were used at the start to the end of the sampling season in April and May, 2004. This period, before canopy closure, was chosen because it is always the most active, but short, period of flowering (Macior 1978; Schemske et al. 1978; Helenurm and Barrett 1987).

Each of the seven sites was sampled for insects on sunny days when the temperature was at least $12{ }^{\circ} \mathrm{C}$. Sampling walks started at either 11:30 or 14:30, the period of relatively high-flower visitation by insects (H. Taki, personal observation). Thus, in most cases, two sites were sampled on 1 day. The order in which the seven sites were sampled was randomly selected by numbered chits in a bag and that order considered as one cycle. Four sampling cycles were made to ensure that sampling was carried out twice at 11:30 and twice at 14:30 for each of the seven sites (i.e., each site was observed on four different days). All samplings were made from 24 April to 28 May in 2004.

At each sampling, the same two people walked the perimeter of the hexagons five times at a slow pace; one person walking clockwise and the other walking anti-clockwise. Each of these samplings took between 80 and $100 \mathrm{~min}$ to complete. Insects seen visiting flowers within $2 \mathrm{~m}$ on either side of the perimeter rope were sampled with insect nets or aspirators. Only insects in the orders Coleoptera, Diptera Hymenoptera, and Lepidoptera were collected. The species of the flowering plant visited by each captured insect was recorded.

The species richness and abundance of all flowering plants in bloom at each site at each site were recorded using a quadrate method (Knapp 1984) with 1 x $1 \mathrm{~m}$ quadrates placed every meter along each side of the perimeter of each hexagon; 20 quadrates along the outer perimeter of each side and 19 along the inner (234 quadrates in total for each recording). The cataloguing and census of plants took place four times for each site, coinciding with the first, second, third, and fourth insect sampling cycle (above). Most of plants observed plant species were identified in situ, but after each sampling one specimen of each species was brought back to the laboratory at the University of Guelph to confirm identification.

\section{Degree of habitat loss}

Circles of various radii from 120 to $2,020 \mathrm{~m}$ (100-2,000 $\mathrm{m}$ from the hexagonal transects) with $100 \mathrm{~m}$ intervals were created, using ArcView, on maps around each of the hexagonal transects to quantify the amount of forest coverage. The scale for these circles was chosen 
from known scale-dependent effects of, and foraging ranges of, flower-visiting insects, such as bees (vanNieuwstadt and Iraheta 1996; Osborne et al. 1999; Steffan-Dewenter et al. 2001, 2002; Gathmann and Tscharntke 2002) and moths (Ricketts et al. 2001). The degree of habitat loss was estimated by the amount of forest coverage $\left(\mathrm{m}^{2}\right)$ within the circles.

Correlation coefficients between forest coverage at each of the radii and the number of plant species found in each hexagonal transect were calculated. Then, the radius with the highest correlation between the forest coverage and the plant species richness was selected for the further analyses (Ricketts 2001; Pearman 2002). We use plant species richness, rather than insect species richness, to avoid the intrinsic bias of actively sampling insects from flowers (rather than passively through e.g., pan traps, malaise traps).

\section{Degree of specialization/generalization}

To quantify the degree of specialization/generalization in our study communities, two steps were used. The first was to quantity the degree $(G)$ of specialization/generalization for each species of plant and insect by Medan et al.'s (2006) index. The second step was to quantify the degree $(C)$ of specialization/generalization for each of the communities represented by the seven study sites by using the average index weighted for abundance of both insects and plants.

Medan et al.'s (2006) index $(G)$ is calculated from two aspects named resource usage $(R)$ and evenness $(E)$. The resource usage of species $i\left(R_{i}\right)$ is computed as:

$$
R_{i}=\frac{S_{i}}{N}
$$

where $S_{i}$ is the number of partner species (either plants or insects) interacting with species $i$ (either insects or plants), and $N$ is the total number of species on the partners' side (either plants or insects) of the community. In our study, when species $i$ was found in more than one community, $S_{i}$ and $N$ were obtained from all of the communities in which it was found.

The other aspect, evenness of species $i\left(E_{i}\right)$, was calculated using the Shannon evenness measure (Magurran 2004) as:

$$
E_{i}=\frac{-\sum_{j} p_{j} \cdot \ln p_{j}}{\ln S_{i}},
$$

where $S_{i}$ is the number of partner species (either plants or insects) interacting with species $i$ (either insects or plants), and $p_{j}$ is the proportion of individuals corresponding to the $j$ th partner species of the given species $i$. When species $i$ has only one partner species, $E_{i}$ cannot be computed because $\ln S_{i},=0$. In this case, Medan et al. (2006) assign a value of 1 .

Using the calculated $R_{i}$ and $E_{i}$, the specialization/generalization index for species $i\left(G_{i}\right)$ was obtained by:

$$
G_{i}=R_{i} \cdot E_{i}
$$

where $G_{i}$ takes a value from 0 to 1 . Species $i$ can be considered as a highly specialized species when it approaches 0 and it can be considered as an extremely generalized species when it reaches 1 . 
For the second step, based on specialization/generalization index $(G)$ for each species, the degree of specialization/generalization for each of the seven study sites was quantified. The degree of specialization/generalization in the community $k\left(C_{k}\right)$ was calculated by the following equation:

$$
C_{k}=\sum_{i}^{D} \frac{G_{i} \cdot t_{i}}{t_{D}}
$$

where $D$ is the total number of species in community $k . t_{i}$ is the total number of individuals of species $i$ for insects or the total number of quadrates encompassing plant species $i$ for plants. $t_{D}$ is the total number of individuals in community $k$ for insects or the total number of quadrates encompassing the found plant species in the community $k$ for plants. The degrees of specialization/generalization for communities $(C)$ were obtained for both plant and insect communities, respectively.

\section{Statistical analysis}

Regression analyses, including linear, power $[\ln (x)$ and $\ln (y+1)]$, semilog $[\ln (x)$ or $\ln (y+1)]$, reciprocal $(1 / x$ or $1 / y)$ functions, were made. Here, the dependent variable $(y)$ is the degree of specialization/generalization for both plant and insect communities, and the independent variable $(x)$ is the degree of habitat loss, described by the amount of forest coverage. The statistical computations were made by PROC GLM of SAS (Version 8.2, SAS Institute, Cary, NC, USA). All hypotheses were tested using a Type I error rate of 0.05 .

\section{Results}

Degree of habitat loss

In total, 27 plant species were in bloom during the study (Table 1). A correlation coefficient between the number of the plant species found and the amount of forest coverage in the seven sites was calculated at each of the 20 radii from 120 to 2,020 m (Fig. 1). Because the plant species richness was most strongly correlated with forest coverage at the $220 \mathrm{~m}$ radius $(0.70)$, the $220 \mathrm{~m}$ radius was used as the scale in all subsequent analyses.

\section{Degree of specialization/generalization}

In total, 394 individual insects in 89 species (including morphological taxonomic units), representing 394 interactions, were found from 18 plant species (Tables 1, 2). Apart from the 394 individual insects, there were four more insect individuals collected, two female specimens of Anthomyiidae from the flowers of Alliaria petiolata (Brassicaceae) and Viola pubescens (Violaceae) and two specimens of Syrphus (Syrphidae) from the flowers of $A$. petiolata. However, because of difficulties in their identification, based on morphological taxonomy, they were not included in the analyses. 


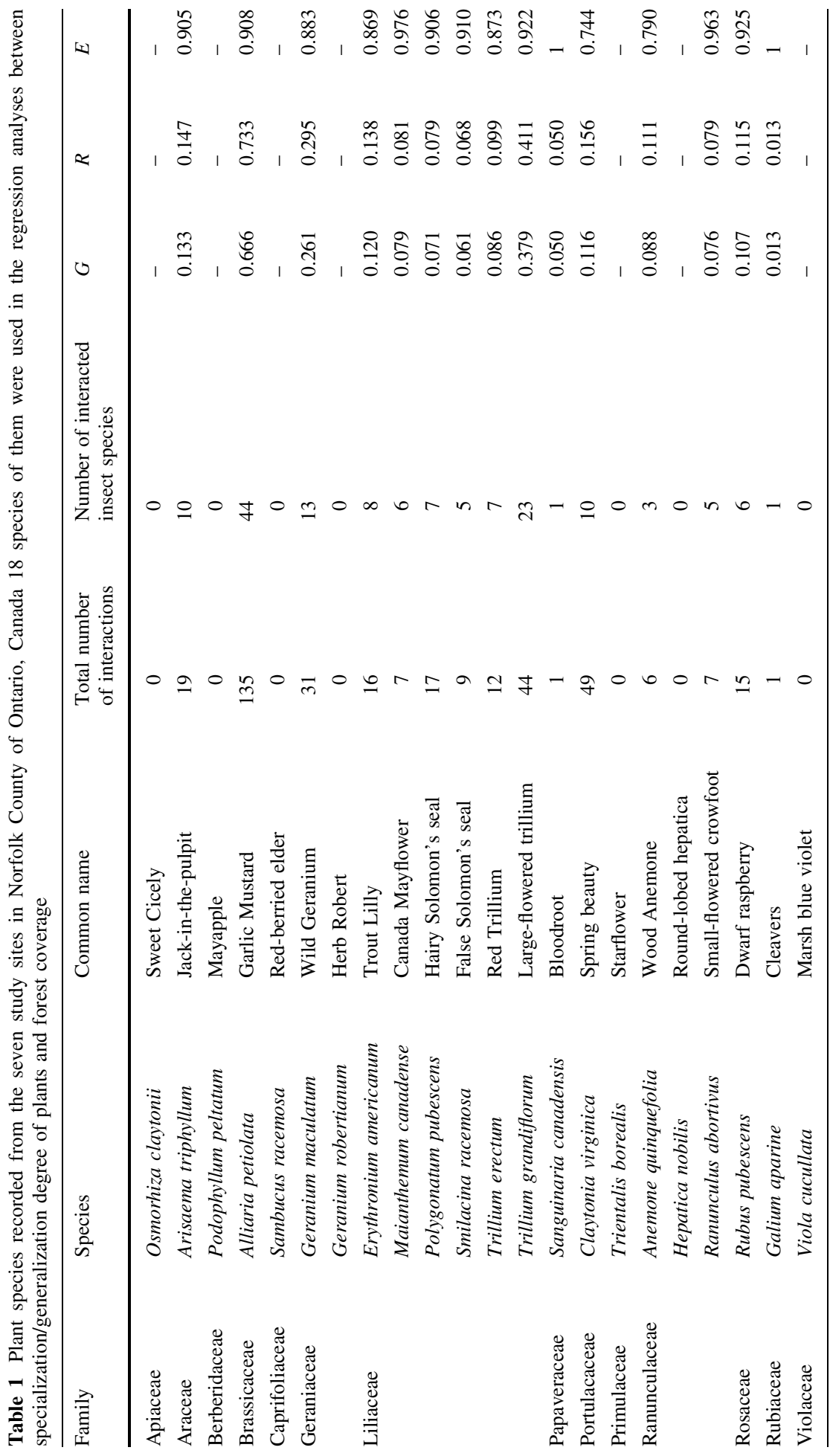




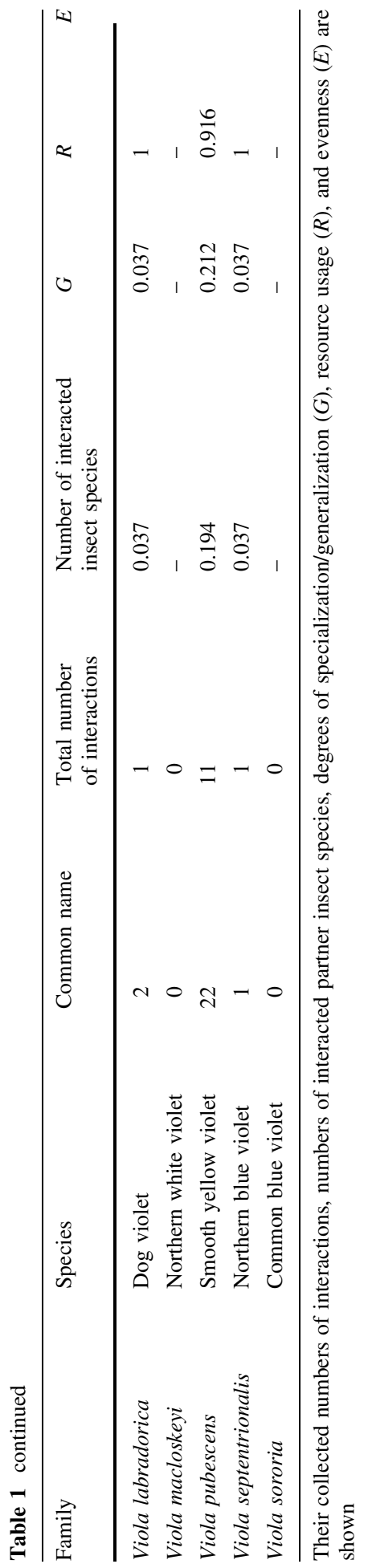




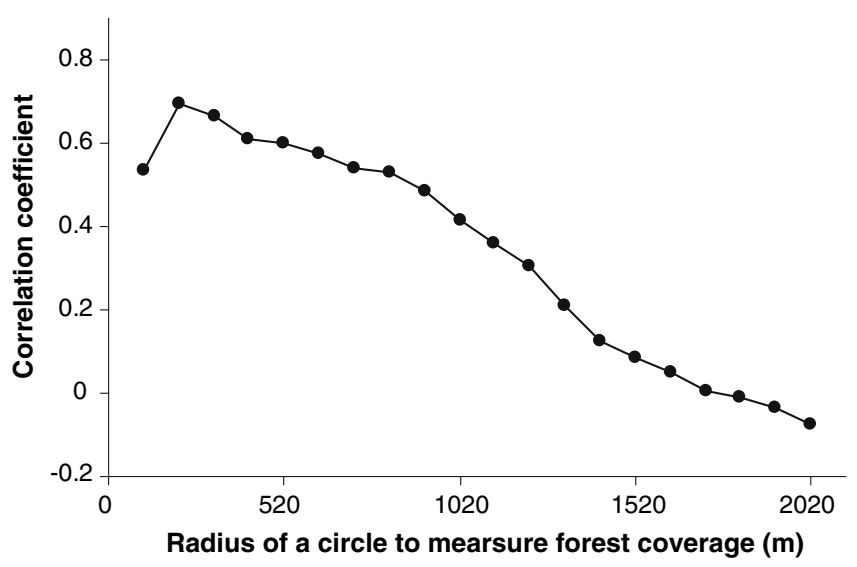

Fig. 1 Correlation coefficients between the percentage of forest coverage at each radius from 120 to $2,020 \mathrm{~m}$ (100-2,000 $\mathrm{m}$ from the hexagonal transects) and $\ln$ (the number of plant species) among the seven study sites. The highest correlation coefficient $(0.70)$ was found at the radius of $220 \mathrm{~m}$

Any of the regression analyses for plant communities, including linear $\left(F_{1,5}=2.03\right.$, $P=0.214)$, power $\left(F_{1,5}=3.05, P=0.141\right)$, semilog $\left[\ln (x): F_{1,5}=2.77, P=0.157\right.$, and $\left.\ln (y+1): F_{1,5}=2.23, P=0.196\right]$, reciprocal $\left(1 / x: F_{1,5}=3.82, P=0.108\right.$, and $1 / y$ : $\left.F_{1,5}=3.92, P=0.105\right)$ functions, indicated that there was no significant relationship between the degree of habitat loss and degree of specialization/generalization in plants (Fig. 2a).

Among the regression analyses, the model of best fit for insect communities was the reciprocal of the forest coverage $\left(R^{2}=0.570\right)$, which indicated a significant relationship between the degree of habitat loss and degree of specialization/generalization in insects $\left(F_{1,5}=6.62, P=0.0498\right)$ (Fig. $\left.2 b\right)$. The other functions, linear $\left(F_{1,5}=4.64, P=0.084\right.$, $\left.R^{2}=0.481\right)$, power $\left(F_{1,5}=5.48, P=0.066, R^{2}=0.523\right)$, semilogs $\left[\ln (x): F_{1,5}=5.66\right.$, $P=0.063, R^{2}=0.531$, and $\left.\ln (y+1): F_{1,5}=4.58, P=0.085, R^{2}=0.478\right]$ and reciprocal of the degree of specialization/generalization $\left(F_{1,5}=3.53, P=0.119, R^{2}=0.414\right)$, showed no significances.

\section{Discussion}

Our results indicate no relationship between degree of habitat loss and degree of specialization/generalization in the plant communities, but a significant relationship between the reciprocal of degree of habitat loss and degree of specialization/generalization exhibited by the communities of insects was found. That implies that pollinators do tend to be more generalized as habitat loss increases although the relationship is not linear.

Insects associated with plant-pollinator interactions appear to be more vulnerable to habitat loss than do the partner plants. The flowers of our study plants had anywhere from 0 to 44 species of insect visitor, but the insects were more fastidious, interacting with 1 to 7 species of plant (Tables 1,2). That result probably reflects only that there are far more insect species than plant species (Wilson 1992) but suggests that the insects involved in pollination interactions generally have narrower niches than do the partner plants. That, in turn implies the greater vulnerability of insects in the system. The much greater longevity, and persistence, of plants following habitat loss further emphasizes the lesser vulnerability 
Table 2 Insect species collected from the seven study sites in Norfolk County of Ontario, Canada, used in the regression analyses between degree of specialization/generalization and forest coverage

\begin{tabular}{|c|c|c|c|c|c|c|}
\hline Order/family & Species & $\begin{array}{l}\text { Total number } \\
\text { of interactions }\end{array}$ & $\begin{array}{l}\text { Number of } \\
\text { interacted } \\
\text { plant species }\end{array}$ & $G$ & $R$ & $E$ \\
\hline \multicolumn{7}{|l|}{ Coleoptera } \\
\hline Byturidae & Byturus unicolor & 10 & 3 & 0.112 & 0.130 & 0.859 \\
\hline \multirow[t]{2}{*}{ Cantharidae } & Silis sp. & 1 & 1 & 0.091 & 0.091 & 1 \\
\hline & Rhagonycha sp. & 1 & 1 & 0.091 & 0.091 & 1 \\
\hline \multirow[t]{2}{*}{ Cerambycidae } & Analeptura lineola & 1 & 1 & 0.091 & 0.091 & 1 \\
\hline & Pidonia ruficollis & 3 & 1 & 0.067 & 0.067 & 1 \\
\hline Curculionidae & Phyllobius oblongus & 6 & 3 & 0.132 & 0.143 & 0.921 \\
\hline \multirow[t]{2}{*}{ Nitidulidae } & Meligethes nigrescens & 6 & 2 & 0.054 & 0.083 & 0.650 \\
\hline & Boreades abdominalis & 4 & 1 & 0.056 & 0.056 & 1 \\
\hline Oedemeridae & Oxycopis thoracica & 10 & 2 & 0.149 & 0.154 & 0.971 \\
\hline Pyrochroidae & Pedilus lugubris & 4 & 2 & 0.090 & 0.111 & 0.811 \\
\hline Scarabaeidae & Hoplia trifasciata & 7 & 1 & 0.077 & 0.077 & 1 \\
\hline \multicolumn{7}{|l|}{ Diptera } \\
\hline \multirow[t]{2}{*}{ Anthomyiidae } & Delia sp. 1 & 5 & 3 & 0.131 & 0.136 & 0.960 \\
\hline & Delia sp. 2 & 1 & 1 & 0.077 & 0.077 & 1 \\
\hline Chironomidae & Chironomidae sp. & 1 & 1 & 0.091 & 0.091 & 1 \\
\hline \multirow[t]{5}{*}{ Mycetophilidae } & Anatella sp. & 1 & 1 & 0.077 & 0.077 & 1 \\
\hline & Docosia sp. & 5 & 1 & 0.043 & 0.043 & 1 \\
\hline & Mycetophila sp. & 4 & 1 & 0.045 & 0.045 & 1 \\
\hline & Phronia sp. & 1 & 1 & 0.077 & 0.077 & 1 \\
\hline & Mycetophilidae sp. 5 & 1 & 1 & 0.077 & 0.077 & 1 \\
\hline Phoridae & Megaselia sp. & 1 & 1 & 0.111 & 0.111 & 1 \\
\hline \multirow[t]{2}{*}{ Rhagionidae } & Rhagio plumbeus & 1 & 1 & 0.111 & 0.111 & 1 \\
\hline & Rhagio mystaceus & 1 & 1 & 0.125 & 0.125 & 1 \\
\hline \multirow[t]{5}{*}{ Sciaridae } & Sciara sp. & 2 & 1 & 0.077 & 0.077 & 1 \\
\hline & Sciaridae sp. 2 & 1 & 1 & 0.077 & 0.077 & 1 \\
\hline & Sciaridae sp. 3 & 1 & 1 & 0.111 & 0.111 & 1 \\
\hline & Sciaridae sp. 4 & 1 & 1 & 0.111 & 0.111 & 1 \\
\hline & Sciaridae sp. 5 & 5 & 1 & 0.091 & 0.091 & 1 \\
\hline \multirow[t]{10}{*}{ Syrphidae } & Brachyopa ferruginea & 2 & 1 & 0.077 & 0.077 & 1 \\
\hline & Brachypalpus oarus & 1 & 1 & 0.091 & 0.091 & 1 \\
\hline & Criorhina sp. & 1 & 1 & 0.167 & 0.167 & 1 \\
\hline & Helophilus fasciatus & 5 & 2 & 0.121 & 0.125 & 0.971 \\
\hline & $\begin{array}{l}\text { Melanostoma } \\
\text { mellinum }\end{array}$ & 3 & 2 & 0.102 & 0.111 & 0.918 \\
\hline & Platycheirus sp. & 1 & 1 & 0.077 & 0.077 & 1 \\
\hline & Shaerophoria sp. & 2 & 1 & 0.167 & 0.167 & 1 \\
\hline & Syrphus rectus & 1 & 1 & 0.077 & 0.077 & 1 \\
\hline & Syrphus ribesii & 14 & 3 & 0.060 & 0.130 & 0.463 \\
\hline & $\begin{array}{l}\text { Toxomerus } \\
\quad \text { geminatus }\end{array}$ & 7 & 3 & 0.114 & 0.158 & 0.725 \\
\hline
\end{tabular}


Table 2 continued

\begin{tabular}{|c|c|c|c|c|c|c|}
\hline Order/family & Species & $\begin{array}{l}\text { Total number } \\
\text { of interactions }\end{array}$ & $\begin{array}{l}\text { Number of } \\
\text { interacted } \\
\text { plant species }\end{array}$ & $G$ & $R$ & $E$ \\
\hline \multirow[t]{3}{*}{ Tachinidae } & Epalpus sp. & 2 & 1 & 0.167 & 0.167 & 1 \\
\hline & Gonia sp. & 1 & 1 & 0.167 & 0.167 & 1 \\
\hline & Siphona sp. & 5 & 1 & 0.056 & 0.056 & 1 \\
\hline \multicolumn{7}{|l|}{ Hymenoptera } \\
\hline \multirow[t]{13}{*}{ Andrenidae } & Andrena sp. & 2 & 1 & 0.167 & 0.167 & 1 \\
\hline & Andrena carlini & 16 & 5 & 0.177 & 0.200 & 0.884 \\
\hline & Andrena crataegi & 7 & 1 & 0.063 & 0.063 & 1 \\
\hline & Andrena distans & 6 & 1 & 0.053 & 0.053 & 1 \\
\hline & Andrena erigeniae & 24 & 2 & 0.038 & 0.154 & 0.250 \\
\hline & Andrena erythronii & 6 & 2 & 0.141 & 0.154 & 0.918 \\
\hline & Andrena milwaukeensis & 4 & 2 & 0.085 & 0.105 & 0.811 \\
\hline & Andrena nivalis & 1 & 1 & 0.077 & 0.077 & 1 \\
\hline & Andrena rufosignata & 1 & 1 & 0.077 & 0.077 & 1 \\
\hline & Andrena rugosa & 5 & 1 & 0.167 & 0.167 & 1 \\
\hline & Andrena spiraeana & 1 & 1 & 0.056 & 0.056 & 1 \\
\hline & Andrena tridens & 3 & 3 & 0.231 & 0.231 & 1 \\
\hline & Andrena vicina & 11 & 5 & 0.170 & 0.200 & 0.849 \\
\hline \multirow[t]{11}{*}{ Apidae } & Apis mellifera & 9 & 3 & 0.116 & 0.150 & 0.773 \\
\hline & Bombus bimaculatus & 8 & 3 & 0.112 & 0.167 & 0.670 \\
\hline & Bombus impatiens & 3 & 2 & 0.087 & 0.095 & 0.918 \\
\hline & Bombus perplexus & 4 & 2 & 0.071 & 0.087 & 0.811 \\
\hline & Bombus vagans & 3 & 2 & 0.080 & 0.087 & 0.918 \\
\hline & Ceratina calcarata & 9 & 7 & 0.329 & 0.350 & 0.941 \\
\hline & Nomada cressonii & 6 & 2 & 0.184 & 0.200 & 0.918 \\
\hline & Nomada lepida & 1 & 1 & 0.077 & 0.077 & 1 \\
\hline & Nomada maculata & 10 & 4 & 0.224 & 0.286 & 0.785 \\
\hline & Nomada ovata & 1 & 1 & 0.167 & 0.167 & 1 \\
\hline & Nomada sayi & 1 & 1 & 0.167 & 0.167 & 1 \\
\hline \multirow[t]{12}{*}{ Halictidae } & Agapostemon sericeus & 7 & 2 & 0.074 & 0.125 & 0.592 \\
\hline & Augochlora pura & 6 & 4 & 0.179 & 0.200 & 0.896 \\
\hline & Halictus confusus & 7 & 2 & 0.075 & 0.087 & 0.863 \\
\hline & Halictus rubicundus & 3 & 1 & 0.167 & 0.167 & 1 \\
\hline & Lasioglossum (Dialictus) coeruleum & 3 & 2 & 0.102 & 0.111 & 0.918 \\
\hline & Lasioglossum (Dialictus) creberrimum & 5 & 3 & 0.131 & 0.136 & 0.960 \\
\hline & Lasioglossum (Dialictus) cressonii & 16 & 6 & 0.201 & 0.231 & 0.871 \\
\hline & Lasioglossum (Dialictus) laevissimum & 1 & 1 & 0.167 & 0.167 & 1 \\
\hline & $\begin{array}{l}\text { Lasioglossum (Dialictus) } \\
\quad \text { nigroviride }\end{array}$ & 4 & 2 & 0.071 & 0.087 & 0.811 \\
\hline & Lasioglossum (Dialictus) pilosum & 1 & 1 & 0.167 & 0.167 & 1 \\
\hline & Lasioglossum (Dialictus) versans & 18 & 4 & 0.133 & 0.160 & 0.829 \\
\hline & Lasioglossum (Dialictus) sp. 1 & 3 & 1 & 0.167 & 0.167 & 1 \\
\hline
\end{tabular}


Table 2 continued

\begin{tabular}{|c|c|c|c|c|c|c|}
\hline Order/family & Species & $\begin{array}{l}\text { Total number } \\
\text { of interactions }\end{array}$ & $\begin{array}{l}\text { Number of } \\
\text { interacted } \\
\text { plant species }\end{array}$ & $G$ & $R$ & $E$ \\
\hline & Lasioglossum (Dialictus) sp. 2 & 1 & 1 & 0.091 & 0.091 & 1 \\
\hline & $\begin{array}{l}\text { Lasioglossum } \\
\quad \text { (Evylaeus) foxii }\end{array}$ & 4 & 4 & 0.174 & 0.174 & 1 \\
\hline & $\begin{array}{l}\text { Lasioglossum } \\
\quad \text { (Evylaeus) quebecense }\end{array}$ & 27 & 6 & 0.195 & 0.240 & 0.812 \\
\hline & $\begin{array}{l}\text { Lasioglossum } \\
\quad \text { (Lasioglossum) coriaceum }\end{array}$ & 5 & 3 & 0.137 & 0.158 & 0.865 \\
\hline & $\begin{array}{l}\text { Lasioglossum } \\
\quad \text { (Lasioglossum) paraforbesii }\end{array}$ & 1 & 1 & 0.111 & 0.111 & 1 \\
\hline & Sphecodes ranunculi & 2 & 2 & 0.091 & 0.091 & 1 \\
\hline \multirow[t]{3}{*}{ Megachilidae } & Osmia atriventris & 1 & 1 & 0.125 & 0.125 & 1 \\
\hline & Osmia caerulescens & 1 & 1 & 0.167 & 0.167 & 1 \\
\hline & Osmia sandhouseae & 1 & 1 & 0.091 & 0.091 & 1 \\
\hline Eulophidae & Eulophidae sp. 1 & 1 & 1 & 0.111 & 0.111 & 1 \\
\hline Pompilidae & Priocnemis minorata & 1 & 1 & 0.167 & 0.167 & 1 \\
\hline Vespidae & Dolichovespula arenaria & 2 & 1 & 0.077 & 0.077 & 1 \\
\hline \multicolumn{7}{|l|}{ Lepidoptera } \\
\hline Lycaenidae & Celastrina ladon & 1 & 1 & 0.167 & 0.167 & 1 \\
\hline
\end{tabular}

Their collected numbers of interactions, numbers of interacted partner plant species, degrees of specialization/ generalization $(G)$, resource usage $(R)$, and evenness $(E)$ are shown

of the plants, at least in the short-term. Moreover, insects, by comparison with plants, have more specific, other needs, such as for food, mating, resting, nesting or oviposition, and avoidance of death (Buchmann and Nabhan 1996; Kearns et al. 1998; Kevan 1999). All in all, insects can be assumed to be more vulnerable to habitat loss than are plants in the case of their mutualistic pollination interactions.

Other explanations for the lack of significant relationship between habitat loss and degree of specialization/generalization in plant communities may be associated with their reproductive systems. Some plants reproduce vegetatively (Abrahamson 1980), and many plants have populations that differ in sexual reproductive strategy (Richards 1997). Aizen et al. (2002) assessed 46 plant species and found that in fragmented habitats the pollination and sexual reproductive success of specialist plants was not significantly different from that of generalist plants, a finding that at least partially supports our conclusions.

We analyzed plant and insect communities separately. Although plant-pollinator networks which exhibit mutualistisms are thought to result from coevolution (Faegri and van der Pij1 1979), recent studies note that asymmetric interactions between plants and pollinators are common (Johnson and Steiner 2000; Vázquez and Aizen 2004; Larsson 2005; Bascompte et al. 2006; Waser and Ollerton 2006). In asymmetric interactions, specialist plants do not always interact with specialist pollinators, as is also the case with generalist plants and generalist pollinators (Ashworth et al. 2004). Our results from separated analyses of plants and insects provide an example of asymmetric interactions at the community level.

In our study, the degree of habitat loss was quantified using a landscape approach before ensuing analyses of specialization/generalization were considered. Similarly, Vázquez and Simberloff (2002) tested the effects of grazing by cattle on the weighed specialization and 


\section{(a) Plant}
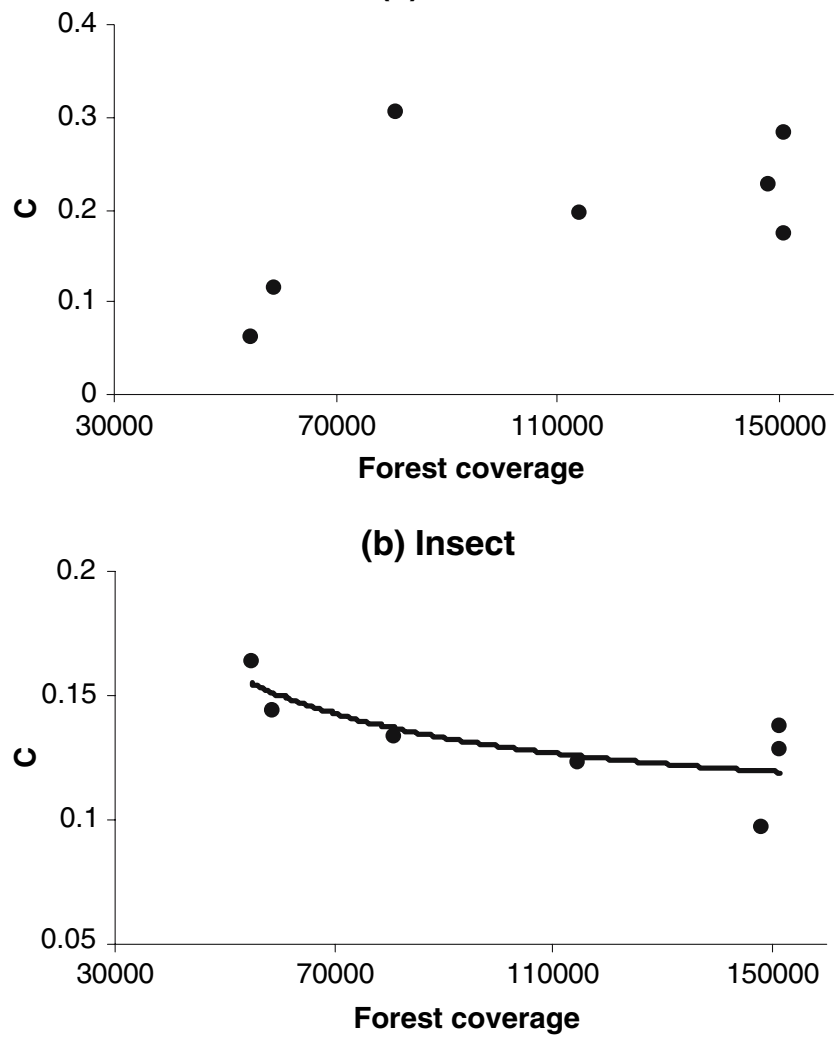

Fig. 2 Relationship between degree of specialization/generalization and forest coverage $\left(\mathrm{m}^{2}\right)$ within a $220 \mathrm{~m}$ radius from the centers of the study transects for the communities of plants (a) and of potential insect pollinators (b). $C$ indicates the degrees of specialization/generalization for either plant or insect communities. Higher $C$ indicates lower specialization. Regression analyses for the plants (a) were not significant $(P>0.05)$. The model of best fit for insects $(\mathbf{b})$ was $Y=0.099-3060.797(1 / X), R^{2}=0.570$, $F_{1,5}=6.62, n=7, P=0.0498$

generalization of species in plant-pollinator interactions by comparing grazed habitats with non-grazed ones. They found no relationship between disturbance and specialization/ generalization in either plants or pollinators. However, they note several reasons why they obtained the results they did and we note that there are many kinds of degradation that vary in degree and form even within grazing lands.

Quantification of the degree of a species' specialization/generalization is most simply done by using the number of its partner species, but an intrinsic bias results because specialist interactions are expected to be observed less often than generalist ones (Vázquez and Aizen 2003). Thus, adjusted or weighted degrees of specialization/generalization are valid and essential. Medan et al.'s (2006) index partially addresses the problem bias. Even so, the results of our study may still be insufficient to understand the impacts of habitat loss on the full network of plant-pollinator interactions. Our sampling was made at only seven sites on four occasions over 1 month in 1 year, for a total of about $6 \mathrm{~h}$ per site. One concern is the possibility of undersampling, as this might affect the calculated degrees of specialization/generalization for any species $(G)$. For example, Andrena crataegi $(G=0.063)$ 
and A. spiraeana (0.056) are indicated as relatively specialized species in our study (Table 2), but Krombein et al. (1976) noted them to be polylectic (generalized). More sampling in time and space could refine our conclusions.

In summary, we quantified both habitat loss and specialization/generalization of each of plant and insect in our study sites and tested the hypothesis that plant and pollinator communities become more generalized with increased loss of habitats. Although our sampling may limit the scope of results, we found a significant relationship between habitat loss and specialization/generalization in the communities of insects but not in plants. In plant-pollinator networks, pollinators seem to be more sensitive and/or quicker to respond than plants to habitat loss. Nonetheless, because it is expected that losses of pollinators would eventually lead plant extinctions (Janzen 1974; Kevan 1975; Kevan and Baker 1999; Bond 1994; Memmott et al. 2004), we advocate that our hypotheses and methods be tested with more extensive sampling in other places and over longer durations.

Acknowledgments We would like to greatly thank C. Fuss for her patient assistance with the field and laboratory work. We would also like to thank Long Point Conservation Authority personnel, F. Saul, J. DeCloet, and V. Sinnave for allowing access to the study sites, A. Pawlowski, B. Viana, and J. Trevors for discussion; G. Umphrey for statistical consultant; F. Silva, J. Boone, and G. Huber for their assistance with the selection of the study sites, and C. Connell and Q. Shirk-Luckett for help with GIS. Assistance with the identification of specimens was provided by the followings: C. Sheffield (Apoidea), S. Rigby (Apoidea), M. Buck (Vespidae, Pompilidae, and Anthomyiidae), J. Klymko (Syrphidae), M. Parchami-Araghi (Tachinidae), S. Paiero (Coleoptera and Diptera), O. Lonsdale (Coleoptera and Diptera), and C.A. Lacroix (Rosaceae and Violaceae). Support for this work was provided by a scholarship from the Rotary Foundation, as well as a grant from the Natural Sciences and Engineering Research Council of Canada.

\section{References}

Abrahamson WG (1980) Demography and vegetative reproduction. In: Solbrig OT (ed) Demography and evolution in plant populations. Blackwell, Oxford

Aizen MA, Ashworth L, Galetto L (2002) Reproductive success in fragmented habitats: do compatibility systems and pollination specialization matter? J Vegetat Sci 13:885-892

Allen GM, Eagles PFJ, Price SD (1990) Conserving Carolinian Canada. University of Waterloo Press, Waterloo

Allen-Wardell G, Bernhardt P, Bitner R et al (1998) The potential consequences of pollinator declines on the conservation of biodiversity and stability of food crop yields. Conserv Biol 12:8-17

Ashworth L, Aguilar R, Galetto L et al (2004) Why do pollination generalist and specialist plant species show similar reproductive susceptibility to habitat fragmentation? J Ecol 92:717-719

Baker HG, Hurd PD (1968) Intrafloral ecology. Annu Rev Entomol 13:385-415

Banaszak J (1980) Studies on methods of censuring the numbers of bees (Hymenoptera, Apoidea). Pol Ecol Stud 6:355-365

Bascompte J, Jordano P, Olesen JM (2006) Asymmetric coevolutionary networks facilitate biodiversity maintenance. Science 312:431-433

Bond WJ (1994) Do mutualisms matter-assessing the impact of pollinator and disperser disruption on plant extinction. Philos Trans R Soc Lond Ser B Biol Sci 344:83-90

Buchmann SL, Nabhan GP (1996) The forgotten pollinators. Island Press, Washington DC

Debinski DM, Holt RD (2000) A survey and overview of habitat fragmentation experiments. Conserv Biol 14:342-355

Dicks LV, Corbet SA, Pywell RF (2002) Compartmentalization in plant-insect flower visitor web. J Anim Ecol 71:32-43

Ewers RM, Didham RK (2006) Confounding factors in the detection of species responses to habitat fragmentation. Biol Rev 81:117-142

Faegri K, van der Pijl L (1979) The principles of pollination ecology, 3rd edn. Pergamon, London

Fahrig L (2003) Effects of habitat fragmentation on biodiversity. Annu Rev Ecol Syst 34:487-515

Findlay CS, Houlahan J (1997) Anthropogenic correlates of species richness in southeastern Ontario wetlands. Conserv Biol 11:1000-1009 
Fortuna MA, Bascompte J (2006) Habitat loss and the structure of plant-animal mutualistic networks. Ecol Lett 9:278-283

Gathmann A, Tscharntke T (2002) Foraging ranges of solitary bees. J Anim Ecol 71:757-764

Gurd DB, Nudds TD, Rivard DH (2001) Conservation of mammals in eastern North American wildlife reserves: how small is too small? Conserv Biol 15:1355-1363

Helenurm K, Barrett SCH (1987) The reproductive biology of boreal forest herbs II. Phenology of flowering and fruiting. Can J Bot 65:2047-2056

Herrera CM (1988) Variation in mutualisms - the spatio-teporal mosaic of a pollinator assemblage. Biol J Linn Soc 35:95-125

Janzen DH (1974) The deflowering of Central America. Nat Hist 83:48-53

Johnson SD, Steiner KE (2000) Generalization versus specialization in plant pollination systems. Trends Ecol Evol 15:140-143

Kassen R (2002) The experimental evolution of specialists, generalists, and the maintenance of diversity. J Evol Biol 15:173-190

Kearns CA, Inouye DW, Waser NM (1998) Endangered mutualisms: the conservation of plant-pollinator interactions. Annu Rev Ecol Syst 29:83-112

Kevan PG (1975) Pollination and environmental conservation. Environ Conserv 2:293-298

Kevan PG (1999) Pollinators as bioindicators of the state of the environment: species, activity and diversity. Agric Ecosyst Environ 74:373-393

Kevan PG (2001) Pollination: a plinth, pedestal, and pillar for terrestrial productivity: the why, how, and where of pollination protection, conservation, and promotion. In: Stubbs CS, Drummond FA (eds) Bees and crop pollination-crisis, crossroads, conservation. Thomas Say Publications in Entomology, Proceedings, Lanham

Kevan PG, Baker HG (1983) Insects as flower visitors and pollinators. Annu Rev Entomol 28:407-453

Kevan PG, Baker HG (1999) Insects on flowers: pollination and floral visitations. In: Huffaker CB, Rabb RC (eds) Insect ecology, 2nd edn. Wiley, New York

Kitahara M, Fujii K (1994) Biodiversity and community structure of temperate butterfly species within a gradient of human disturbance - an analysis based on the concept of generalist vs specialist strategies. Res Popul Ecol 36:187-199

Kitahara M, Sei K, Fujii K (2000) Patterns in the structure of grassland butterfly communities along a gradient of human disturbance: further analysis based on the generalist/specialist concept. Res Popul Ecol 42:135-144

Knapp R (1984) Conservations on quantitative parameters and qualitative attributes in vegetation analysis and in phytosociological relevés. In: Knapp R (ed) Sampling methods and taxon analysis in vegetation science. Dr W. Junk Publishers, The Hague

Krombein KV, Hurd PD, Smith DR et al (1979) Catalog of Hymenoptera in America north of Mexico. Smithsonian Institution Press, Washington DC

Larsson M (2005) Higher pollinator effectiveness by specialist than generalist flower-visitors of unspecialized Knautia arvensis (Dipsacaceae). Oecologia 146:394-403

Macior LW (1978) Pollination ecology of vernal angiosperms. Oikos 30:452-460

Magurran AE (2004) Measuring biological diversity. Blackwell Publishing, Oxford

Medan D, Basilio AM, Devoto M et al (2006) Measuring generalization and connectance in temperate, yearlong active systems. In: Waser NM, Ollerton J (eds) Plant-pollinator interactions: from specialization to generalization. University of Chicago Press, Chicago

Memmott J (1999) The structure of a plant-pollinator food web. Ecol Lett 2:276-280

Memmott J, Waser NM, Price MV (2004) Tolerance of pollination networks to species extinctions. Proc R Soc Lond Ser B Biol Sci 271:2605-2611

Olesen JM, Jordano P (2002) Geographic patterns in plant-pollinator mutualistic networks. Ecology $83: 2416-2424$

Osborne JL, Clark SJ, Morris RJ et al (1999) A landscape-scale study of bumble bee foraging range and constancy, using harmonic radar. J Appl Ecol 36:519-533

Pearman PB (2002) The scale of community structure: habitat variation and avian guilds in tropical forest understory. Ecol Monogr 72:19-39

Proctor MCF (1978) Insect pollination syndromes in an evolutionary and ecosystemic context. In: Richards AJ (ed) The pollination of flowers by insects. Academic Press, London

Richards AJ (1997) Plant breeding systems, 2nd edn. Chapman and Hall, London

Rathcke BJ, Jules ES (1993) Habitat fragmentation and plant pollinator interactions. Curr Sci 65:273-277

Ricketts TH (2001) The matrix matters: effective isolation in fragmented landscapes. Am Nat 158:87-99

Ricketts TH, Daily GC, Ehrlich PR et al (2001) Countryside biogeography of moths in a fragmented landscape: biodiversity in native and agricultural habitats. Conserv Biol 15:378-388 
Schemske DW, Willson MF, Melampy MN et al (1978) Flowering ecology of some spring woodland herbs. Ecology 59:351-366

Stebbins GL (1970) Adaptive radiation in angiosperms I. Pollination mechanisms. Annu Rev Ecol Syst 12:307-326

Steffan-Dewenter I, Münzenberg U, Tscharntke T (2001) Pollination, seed set and seed predation on a landscape scale. Proc R Soc Lond Ser B Biol Sci 268:1685-1690

Steffan-Dewenter I, Münzenberg U, Bürger C et al (2002) Scale-dependent effects of landscape context on three pollinator guilds. Ecology 83:1421-1432

Steffan-Dewenter I, Tscharntke T (2002) Insect communities and biotic interactions on fragmented calcareous grasslands-a mini review. Biol Conserv 104:275-284

Tscharntke T, Brandl R (2004) Plant-insect interactions in fragmented landscapes. Annu Rev Entomol 49:405-430

vanNieuwstadt MGL, Iraheta CER (1996) Relation between size and foraging range in stingless bees (Apidae, Meliponinae). Apidologie 27:219-228

Vázquez DP, Simberloff D (2002) Ecological specialization and susceptibility to disturbance: conjectures and refutations. Am Nat 159:606-623

Vázquez DP, Aizen MA (2003) Null model analyses of specialization in plant-pollinator interactions. Ecology 84:2493-2501

Vázquez DP, Aizen MA (2004) Asymmetric specialization: a pervasive feature of plant-pollinator interactions. Ecology 85:1251-1257

Waser NM, Chittka L, Price MV et al (1996) Generalization in pollination systems, and why it matters. Ecology 77:1043-1060

Waser NM, Ollerton J (2006) Plant-pollinator interactions: from specialization to generalization. University of Chicago Press, Chicago

Waldron G (2003) Trees of the Carolinian forest: a guide to species, their ecology and uses. Boston Mills Press, Toronto

Wilson DS, Yoshimura J (1994) On the coexistence of specialists and generalists. Am Nat 144:692-707

Wilson EO (1992) The diversity of life. Harvard University Press, Cambridge 